\title{
KEMAMPUAN MAHASISWA DALAM PENDEFINISIAN MASALAH PADA PEMBELAJARAN BERBASIS RISET
}

\author{
(Defining Problems Ability of Students in Research-Based Learning)
}

\author{
Oleh: Trisna Amelia*) \\ Email: trisna.amelia@umrah.ac.id
}

\begin{abstract}
${ }^{*}$ Program Studi Pendidikan Biologi, Fakultas Keguruan dan Ilmu Pendidikan, Universitas Maritim Raja Ali Haji
\end{abstract}

\begin{abstract}
Biology Seminar is a course in Biology Education Study Program of FKIP UMRAH that requires students to have the ability to apply scientific attitudes, perform scientific writing and undertake scientific publications on a small scale. One of the learning strategies that can drive the achievement of learning outcomes is Research-Based Learning. One type of research-based learning is that which facilitates students doing small-scale research. Small-scale research conducted by students applying scientific methods and train students to have a scientific attitude. This paper was derived based on descriptive research conducted to reveal how the defining problem skill formed by research-based learning process. Instrument used was questionnaire and documentations of 44 students brainstorming of the topic. The assessment is given based on several indicators, namely ability; explain the source of the problem, explain the problem phenomenon, identify more than one problem topic, choose the focus of the problem, construct the problem formulation, and find supporting references. From the study it was known that students defining problem skill was in the high category.
\end{abstract}

Key words:

research-based learning, small-scale research, scientific methods, defining problems

\section{PENDAHULUAN}

Pembelajaran berbasis riset menjadi salah satu strategi pembelajaran yang sesuai dengan karakteristik pembelajaran di perguruan tinggi. Tridharma Perguruan Tinggi yang terdiri dari pendidikan, penelitian dan pengabdian merupakan suatu tanggung jawab yang diemban oleh sivitas akademika terutama dosen sebagai tenaga pengajar di perguruan tinggi. Pembelajaran berbasis riset menjadi sangat relevan diterapkan sebagai upaya menjembatani aktivitas pendidikan dan penelitian yang rutin dilakukan dosen.

Pembelajaran berbasis riset merupakan sebuah inovasi pembelajaran yang berlandaskan filosofi kontruktivisme yang mencakup empat aspek yaitu: pembelajaran yang membangun pemahaman mahasiswa, pembelajaran dengan mengembangkan prior knowledge, pembelajaran yang merupakan proses interaksi sosial dan pembelajaran bermakna yang dicapai melalui pengalaman nyata. Pembelajaran berbasis riset merupakan metode pembelajaran yang menggunakan authentic learning, problem-solving, cooperative learning, contextual (hands on \& minds on, dan inquiry discovery approach yang dipandu oleh filosofi konstruktivisme (Roach, 2000). Dalam pembelajaran berbasis riset, pelaksanaan riset dan hasil riset menduduki peranan penting. Riset menjadi sarana yang penting dalam meningkatkan mutu pembelajaran. Komponen riset terdiri dari: latar belakang, prosedur, pelaksanaan, hasil riset dan pembahasan 
serta publikasi hasil riset. Tiap komponen tersebut memberikan kontribusi yang penting dalam pembelajaran dalam meningkatkan kemampuan untuk memformulasi permasalahan, penyelesaian permasalahan, dan mengkomunikasikan manfaat hasil penelitian. Hal inilah yang kemudian berpeluang untuk meningkatkan kualitas proses dan hasil pembelajaran.

Pembelajaran berbasis riset memberikan peluang kepada mahasiswa untuk mencari informasi, menyusun hipotesis, mengumpulkan data, menganalisis data, dan membuat kesimpulan atas data yang sudah tersusun; dalam aktivitas ini berlaku pembelajaran dengan pendekatan learning by doing. Strategi pembelajaran ini memberikan peluang untuk pengembangan metode pembelajaran, antara lain:

1. Pembaharuan pembelajaran (pengayaan kurikulum) dengan mengintegrasikan hasil riset,

2. Partisipasi aktif mahasiswa di dalam pelaksanaan riset,

3. Pembelajaran dengan menggunakan instrumen riset, dan

4. Pengembangan konteks riset secara inklusif (mahasiswa mempelajari prosedur dan hasil riset untuk memahami seluk-beluk sintesis) (Griffith Institute for Higher Education, 2008 dan Widyawati, 2010).

Pada mata kuliah Seminar Biologi, pembelajaran berbasis riset sudah dilakukan mulai tahun akademik 2016/2017. Mata kuliah ini merupakan salah satu bagian dalam struktur kurikulum inti pada Program Studi Pendidikan Biologi FKIP UMRAH, bertujuan untuk membekali mahasiswa dengan kemampuan melakukan penulisan ilmiah dan publikasi ilmiah sebagai output kompetensi. Untuk melakukan penulisan ilmiah, mahasiswa difasilitasi melakukan kajian mendalam mengenai suatu topik yang menarik minat mereka, dengan mempertimbangkan nilai kebaruan ide dan gagasan sehingga berpotensi menjadi tulisan yang berkualitas. Untuk itu, pembelajaran berbasis riset menjadi sangat strategis untuk memfasilitasi mahasiswa dalam membangun karya ilmiahnya.

Berdasarkan kajian deskriptif yang telah dilakukan sebelumnya mengenai skenario pembelajaran berbasis riset pada mata kuliah Seminar Biologi, diperoleh informasi bahwa strategi ini sangat sesuai diterapkan untuk mendorong mahasiswa mencapai produk perkuliahan Seminar Biologi (Amelia, 2018). Strategi pembelajaran berbasis riset yang diterapkan pada pembelajaran Seminar Biologi melalui beberapa cara, di antaranya; memperkaya kegiatan dengan isu-isu penelitian kontemporer, mengajarkan metode penelitian, melakukan kegiatan penelitian skala kecil dan menerapkan nilai-nilai ilmiah yang harus dimiliki seorang peneliti.

Kegiatan penelitian skala kecil (miniriset) yang dilakukan, bertujuan untuk melatih mahasiswa menerapkan metode ilmiah serta sikap dan nilai-nilai ilmiah seorang peneliti. Metode ilmiah yang dilatihkan kepada mahasiswa meliputi : mengidentifikasi masalah, mengajukan hipotesis, merancang penelitian, mengumpulkan data, menganalisis data, dan membuat kesimpulan. Para ilmuwan sepakat bahwa metode ilmiah (saintifik) merupakan pendekatan khusus yang dapat membantu manusia menata pemikirannya untuk memahami proses ilmiah (Mc Pherson,2001).

Mendefinisikan masalah merupakan tahap awal dalam metode ilmiah (Nichols dan April, 2013). Kemampuan mengidentifikasi masalah menjadi kemampuan pertama yang harus dikuasai mahasiswa untuk dapat 
melakukan metode ilmiah lainnya. Mengidentifikasi masalah hendaklah disertai dengan pemahaman terhadap masalah tersebut. Dari perkuliahan Seminar Biologi yang sedang berlangsung, dilakukan kajian deskriptif untuk mengetahui kemampuan pendefinisian masalah mahasiswa dalam proses pelaksanaan mini riset sebagai bentuk tugas proyek di mata kuliah ini.

\section{METODE PENELITIAN}

Pembelajaran berbasis riset diterapkan pada semester genap tahun akademik 2017/2018 (Februari-Mei 2018), pada program studi Pendidikan Biologi FKIP UMRAH. Sampel penelitian meliputi 44 mahasiswa yang sedang mengikuti perkuliahan ini (total sampling). Data penelitian dikumpulkan melalui tiga (3) instrumentasi, yaitu; angket terbuka, dokumentasi hasil brainstorming mahasiswa saat pemilihan topik penulisan, dan dokumentasi proposal mahasiswa. Data dianalisis secara deskriptif eksplanatif dan statistic deskriptif untuk memberikan deskripsi mengenai kemampuan pendefinisian masalah mahasiswa. Indikator kemampuan pendefinisian masalah mengacu pada Polya's Problem Solving Techniques dan Problem-solving Skills Assessment Instrument yang dikembangkan oleh Herak (2010).

\section{HASIL}

Berdasarkan data yang diperoleh melalui angket terbuka dan assesmen dokumentasi portofolio mahasiswa, peroleh nilai kemampuan pendefinisian masalah (KPM) sebagai berikut.

Tabel 1. Persentase kategori nilai KPM mahasiswa

\begin{tabular}{|c|c|c|}
\hline Rentang Nilai KPM & Kategori KPM & Persentase KPM (\%) \\
\hline $0 \leq \mathrm{KPM} \leq 60$ & Rendah & 4.5 \\
\hline $60<\mathrm{KPM} \leq 75$ & Sedang & 50.0 \\
\hline $75<\mathrm{KPM} \leq 100$ & Tinggi & 45.5 \\
\hline
\end{tabular}

Secara umum, KPM mahasiswa berada dalam kategori sedang. Jika ditinjau secara detail berdasarkan indicator KPM, diperoleh data nilai KPM mahasiswa sebagai berikut.

Tabel 2. Nilai KPM untuk Setiap Indikator

\begin{tabular}{|r|l|c|c|}
\hline No. & \multicolumn{1}{|c|}{ Indikator KPM } & Rerata & Kategori \\
\hline 1 & Mampu menjelaskan sumber masalah secara relevan & 93 & Tinggi \\
\hline 2 & Mampu menjelaskan fenomena masalah & 70 & Sedang \\
\hline 3 & $\begin{array}{l}\text { Mampu mengidentifikasi lebih dari 1 topik } \\
\text { berdasarkan masalah }\end{array}$ & 75 & Sedang \\
\hline 4 & $\begin{array}{l}\text { Mampu memilih satu topik/ focus masalah dan } \\
\text { menjelaskan alas an }\end{array}$ & 71 & Sedang \\
\hline 5 & Mampu mengkonstruksi rumusan masalah & 78 & Tinggi \\
\hline 6 & $\begin{array}{l}\text { Mampu menemukan informasi yang relevan sebagai } \\
\text { pendukung pembahasan masalah }\end{array}$ & 80 & Tinggi \\
\hline \multicolumn{2}{|c|}{ Rata-rata nilai } & $\mathbf{7 7 . 8}$ & Tinggi \\
\hline
\end{tabular}


Dari data yang diperoleh, diketahui bahwa KPM tertinggi diperoleh mahasiswa pada kemampuan menjelaskan sumber masalah, namun pada kemampuan menjelaskan fenomena masalah diperoleh nilai paling rendah. Melalui angket terbuka mahasiswa menjelaskan bahwa masalah yang menjadi kajiannya bersumber dari proses observasi lingkungan dan membaca hasil penelitian. Sebagian besar bersumber dari observasi di lingkungan sekolah, kampus, serta keseharian dalam mengamati lingkungan tempat tinggal dan mengikuti pemberitaan. Namun, saat menjelaskan secara rinci fenomena yang mereka temukan (pada Bab 1 Proposal Miniriset), sebagian dari mahasiswa belum mampu menjelaskan fenomena dengan detail dan menarik keterhubungannya dengan topik kajiannya. Di sisi lain mahasiswa dengan nilai tertinggi untuk indicator ini, mampu menjelaskan detail fenomena serta keterkaitannya dengan topik kajiannya. Artinya untuk indicator menjelaskan fenomena masalah, sebagian kecil mahasiswa sudah mampu dengan baik, namun sebagian lainnya masih kurang dan sedang kemampuannya.

$$
\text { Kemampuan menjelaskan }
$$

fenomena masalah, sangat erat hubungannya dengan kemampuan melakukan observasi. Kemampuan melakukan observasi terhadap kejadian, fenomena, dan proses yang berlangsung di sekitar, akan mempengaruhi relevansi masalah yang dikaji. Masalah yang didefinisikan harus mempertimbangkan relevansi dengan kondisi nyata dan kemampuan untuk dilakukan pengujian (Ryan dan Angela, tanpa tahun). Kemampuan menjelaskan fenomena masalah pada sebagian mahasiswa yang masih tergolong rendah dan sedang dapat disebabkan oleh belum maksiml pengamatan (dengan panca indera) yang dilakukan dan masih kurang peka terhadap masalah di lapangan dalam melakukan observasi.

Selanjutnya, kecenderungan hasil kemampuan mengidentifikasi lebih dari satu topik, cenderung linear dengan kemampuan menjelaskan fenomena. Jika mahasiswa mampu menjelaskan fenomena dengan baik dan komprehensif, maka juga muncul kecenderungan untuk mengidentifikasi lebih dari satu topik.

KPM dengan nilai rata-rata paling rendah kedua adalah kemampuan memilih topik/ focus masalah dan menjelaskan alasannya. Pada dasarnya, subketerampilan ini menjadi indicator paling penting dalam kemampuan mendefinisikan masalah. Berdasarkan pemaknaan terhadap 'mendefinisikan masalah' oleh Herak, bahwa mendefinisikan masalah berarti 'justify topic choice', maka pertanyaan utama yang perlu dijawab adalah 'mengapa Anda memilih topik masalah tersebut?’ (Herak, 2010).

\section{PEMBAHASAN}

Berdasarkan data, diketahui bahwa sebagian mahasiswa memiliki kemampuan sedang dalam menjelaskan alasan pemilihan topik, ditandai dengan respon yang diberikan melalui angket terbuka cenderung belum secara komplit memberikan penjelasan.

Berikut merupakan contoh kutipan alasan mahasiswa dalam memilih topik mini riset.

\section{Alasan pemilihan topik pada kategori nilai rendah}

Karena untuk menambah pengalaman dan wawasan terutama tentang penelitian ilmiah dan diharapkan nantinya dapat menjadi pengalaman serta pengetahuan mengenai model pembelajaran dalam usaha meningkatkan kemampuan bekerjasama siswa sma dan dapat menerapkannya dalam proses belajar, mengajar di sekolah.'

Alasan pemilihan topik yang dijelaskan pada kutipan di atas sama sekali belum menggambarkan esensi kajian berkaitan dengan fenomena yang diamati. Demikian juga halnya dengan arti penting kajian terhadap lingkungan terkait juga tidak 
dijelaskan.

2. Alasan pemilihan topik pada kategori nilai sedang

'Karena tidak semua mahasiswa di kalangan kampus Universitas Martitim Raja Ali Haji khususnya di FKIP termotivasi untuk berprestasi ,jadi saya mengambil judul ini agar bisa melihat faktor-faktor motivasi berprestasi apa saja yang memicu seseorang mahasiswa untuk berprestasi.'

Alasan yang diberikan sudah menggambarkan esensi fenomena dan implikasi umum dari kajian, namun belum secara detail memberikan penjelasan.

3. Alasan pemilihan topik pada kategori nilai tinggi

Alasan memilih karya tulis ilmiah tersebut karena di sekolah-sekolah mengalami kekurangan media Nutrient Agar (NA) dikarenakan media tersebut relatif mahal, sehingga perlu media alternatif yang bisa menggantikan media nutrient agar (NA). Media alternatif tersebut harus mengandung nutrisi yang dibutuhkan untuk pertumbuhan bakteri seperti dari bahan-bahan yang kaya akan karbohidrat dan protein. Dalam proposal ini mengambil media alternatif yang kaya akan karbohidrat yaitu umbi-umbian sebagai pengganti dari media nutrient agar (NA). Media alternatif tersebut merupakan bahan-bahan yang mudah didapatkan di alam, serta tidak memerlukan biaya yang mahal sehingga disekolah-sekolah yang kekurangan NA masih bisa melakukan praktikum mengenai materi bakteri dengan menggunakan media alternatif yaitu media umbi-umbian.'

Penjelasan yang diberikan secara detail menggambarkan masalah/ fenomena dan juga memberikan gambaran implikasi umum dari kajian yang akan dilakukan.

Kemampuan memilih dan menjelaskan alasan pemilihan topik merupakan lanjutan dari kemampuan mengobservasi dan menjelaskan fenomena masalah. Observasi yang baik terhadap fenomena merupakan langkah awal dalam metode ilmiah (McPherson, 2001). Berdasarkan kumpulan data, diketahui bahwa mahasiswa dengan kecenderungan mampu secara baik menjelaskan fenomena masalah, juga mampu dengan baik menjelaskan alasan pemilihan topik. Terdapat dua mahasiswa yang memiliki kemampuan rendah dalam menjelaskan fenomena masalah, juga memiliki kemampuan rendah dalam menjelaskan alasan pemilihan topik.

Dalam mengkonstruksi rumusan masalah, secara umum mahasiswa sudah mampu dengan baik melakukannya, hanya saja beberapa masih keliru/ kurang tepat dalam memilih kata tanya. Kemampuan yang sudah baik ini juga didukung oleh pengalaman belajar yang dimiliki mahasiswa, di mana pada semester sebelumnya sudah menyelesaikan mata kuliah metodologi penelitian pendidikan, sehingga sudah memahami prinsip perumusan masalah.

Indikator terakhir adalah kemampuan menemukan informasi relevan sebagai pendukung pembahasan masalah. Indokator ini terwujud dalam bentuk pengarsipan artikel ilmiah dan buku teks yang relevan. Nilai untuk poin ini tinggi dikarenakan mahasiswa memang sudah diinstruksikan untuk mensitasi setidaknya tiga (3) artikel ilmiah nasional dan dua (2) artikel ilmiah internasional serta minimal dua (2) buku teks relevan. Secara umum, sebagian besar sudah mampu memenuhi persyaratan ini, hanya ada beberapa mahasiswa yang kurang satu artikel ilmiah, atau semua artikel ilmiahnya bertaraf nasional.

\section{IMPLIKASI}

Pembelajaran berbasis riset yang diterapkan pada mata kuliah Seminar Biologi secara umum dapat membantu mahasiswa melatih kemampuan pendefinisian masalah (KPM). Ditinjau dari enam (6) indicator KPM, mahasiswa 
memiliki kemampuan relatif sedang dalam hal menjelaskan fenomena masalah, mengidentifikasi lebih dari satu topik masalah, dan menjelaskan alasan pemilihan topik masalah. Untuk indikator kemampuan menjelaskan sumber masalah, merumuskan masalah dan melakukan pengumpulan sumber informasi/ referensi, mahasiswa memiliki nilai kemampuan relatif tinggi. Kajian mengenai pembelajaran berbasis riset ke depan akan berpeluang besar dalam pendidikan tinggi.

\section{REFERENSI}

Amelia, T. (2018). The Implementation of Research-based Learning on Biology Seminar Course in Biology Education Study Program. IOP Conf. Ser.: Mater. Sci. Eng. 335012095.

Griffith Institute for Higher Education. (2008). Research-based Learning: Strategies for Successfully Linking Teaching and Research. University of Griffith. Diakses pada 1 Sept 2017 dari

https://www.griffith.edu.au/learningfutures/pdf/gihe_tipsheet_web_rbl.pdf

Herak, P.J. (2010). Dissertation: Construction and Validation of An Instrument To Measure ProblemSolving Skills of Suburban High School Physical Science Students. The Ohio State University.

McPherson, G.R. (2001). Teaching \& Learning the Scientific Method, Journal of the American Biology Teacher, Volume 63, No. 4. Diakses pada 1 April 2018 dari http://www.virginia.edu/blandy/bland y_web/education/Bay/Teaching\&Lear ningSciMethod_McPherson.pdf

Nichols, A., April S. (2013). The Scientific Method and the Creative Process: Implications for the K-6 Classroom. Journal for Learning through the Arts. Diakses pada 1 April 2018 dari http://escholarship.org/uc/item/0z72t7 $5 \mathrm{q}$

Roach M Blackmore P Dempster J. (2000).
Supporting High-Level Learning Through Research-based Methods: Interim Guideline for Course Design. TELRI Project-University of Warwick. Diakses pada 1 April 2018 http://citeseerx.ist.psu.edu/viewdoc/do wnload

Ryan, M., Angela C. The Scientific Method. University of Nevada. Diakses pada 1 April 2018 dari https://www.unce.unr.edu/publications /files/cd/.../fs0266.pdf

Widayati, et al. (2010 uideline Research-based Learning. uıiversity of Gajah Mada. Diakses pada 1 Sept dari http://ppp.ugm.ac.id/p3/wpcontent/uploads/pupbringgris.pdf 